\title{
Mass loss and imbalance of glaciers along the Andes \\ Cordillera to the sub-Antarctic islands
}

\author{
SEBASTIAN H. MERNILD \\ Glaciology and Climate Change Laboratory, Center for Scientific Studies/Centro \\ de Estudios Cientificos (CECs), CHILE \\ ANDREW P. BECKERMAN \\ Department of Animal and Plant Sciences, University of Sheffield, UK \\ JACOB C. YDE \\ Faculty of Engineering and Science, Sogn og Fjordane University College, \\ NORWAY \\ EDWARD HANNA \\ Department of Geography, University of Sheffield, UK \\ JEPPE K. MALMROS \\ Glaciology and Climate Change Laboratory, Center for Scientific Studies/Centro \\ de Estudios Cientificos (CECs), Valdivia, CHILE, and Department of Geosciences \\ and Natural Resource Management, University of Copenhagen, DENMARK \\ RYAN WILSON \\ Glaciology and Climate Change Laboratory, Center for Scientific Studies/Centro \\ de Estudios Cientificos (CECs), CHILE \\ MICHEAL ZEMP \\ Department of Geography, University of Zurich, Zurich, SWITZERLAND
}

\begin{abstract}
Here, we examine available glacier mass-balance records between 1993 and 2012 for Andes Cordillera, South America $\left(6.5^{\circ} \mathrm{N}-45.8^{\circ} \mathrm{S}\right)$, and the sub-Antarctic islands around the northern tip of the Antarctic Peninsula $\left(62.7^{\circ} \mathrm{S}-63.8^{\circ} \mathrm{S}\right)$ to determine their recent mass loss and imbalance with the present climate. The mean annual observed mass-balance $B_{a}$ changed from $-620 \pm 390$ (1993-2002) to $-740 \pm$ $240 \mathrm{~kg} \mathrm{~m}^{-2} \mathrm{yr}^{-1}$ (2003-2012) and for this past decade showed a decrease in $B_{a}$ from south to north. These glaciers had a mean accumulation area ratio of 0.42 , which is below the AAR value for glaciers in equilibrium, reflecting mean area and volume imbalances of $23 \%$ and $27 \%$, respectively. Glaciers in the northern part of Andes Cordillera are most out of balance with the present climate (33\%), whilst glaciers on the sub-Antarctic islands are only slightly out of balance (4 \%). We identified a spatiotemporal cycle of $B_{a}$ that distinguishes glaciers on the sub-Antarctic islands from glaciers in the Andes using an Empirical Orthogonal Function analysis. This analysis also revealed that South America should be divided into three individual glacier regions, and not two regions as earlier stated. Overall, the spatiotemporal cycles identified correlate to the multivariate El Niño Southern Oscillation Index instantaneous (zero-year lag-time) and to the Pacific Decadal Oscillation with an approximate eight-year lag-time.
\end{abstract}




\section{Introduction}

Glaciers are sensitive to changes in climate, especially surface air temperature and precipitation (AMAP 2011, Chapter 7). Over a year, when the sum of accumulation (mainly due to snowfall) equals the sum of ablation (mainly due to surface melting, runoff, and calving), a glacier is considered to be in annual balance. If the annual accumulation sum is unequal to the ablation sum over a period of years to decades, glaciers are likely to either thin and retreat or thicken and advance. For the last decades most of Earth's glaciers, including South American glaciers (e.g., Georges 2004; Casassa et al. 2007; Masiokas et al. 2008; Rabatel et al. 2011, 2013), have undergone general thinning and recession (e.g., WGMS 2012; IPCC 2013, Chapter 4; Leclercq et al. 2014). Glacier annual mass-balance $\left(B_{a}\right)$ observations from the last decades have shown an overall increase in mass loss (Cogley 2009, 2012; Dyurgerov 2010), resulting in more negative annual $B_{a}$ during the first pentad (five years) of the first decade of the new millennium (WGMS 2013). Although more moderate, these negative $B_{a}$ appear to have been sustained for the second pentad (e.g., Cogley 2012; Marzeion et al. 2014).

Globally, direct $B_{a}$ field measurements exist for 340 glaciers, of which 25 are located in South America and on islands around the northern tip of the Antarctic Peninsula. Despite only representing a minor fraction of the real number of glaciers in South America ( 21,800 glaciers; Radić et al. 2013) and on the sub-Antarctic islands ( 1,000 glaciers; Bliss et al. (2013), this sample of 25 represents an important reference dataset in regards to the health of glaciers in these regions as a whole.

Given the relatively small sample of available direct $B_{a}$ observations, research has to rely on modeling, remote sensing-derived measurements, and upscaling approaches to define and explore trends in $B_{a}$ and associated dynamic imbalance conditions. Specifically, these approaches have been used to estimate global mean glacier $B_{a}$ changes, including $B_{a}$ changes for South America and the Antarctic Peninsula region (e.g., Kaser et al. 2006; Hock et al. 2009; Marzeion et al. 2012; Gardner et al. 2013; Mernild et al. 2013). Gardner et al. (2013), for example, used satellite gravimetry, altimetry, and direct glaciological records to estimate mean glacier $B_{a}$ conditions and ice mass contribution to sea-level rise for the northern and southern Andes (2003-2009). They estimated glacier mass losses of $-1,080 \pm 360$ for northern Andes and $-990 \pm 360 \mathrm{~kg} \mathrm{~m}^{-2} \mathrm{yr}^{-1}$ for central and southern Andes (20032009). Additionally, for Antarctica and the sub-Antarctic region, Gardner et al. (2013) 
estimated a mean glacier mass loss of $-50 \pm 70 \mathrm{~kg} \mathrm{~m}^{-2} \mathrm{yr}^{-1}$ (no separate mass budget rates were estimated for the Antarctic Peninsula alone). Specifically for the northern Antarctic Peninsula ( $<66^{\circ} \mathrm{S}$ ), a mean mass loss of $-72 \mathrm{~kg} \mathrm{~m}^{-2} \mathrm{yr}^{-1}$ has been estimated (pers. com. T. Scambos, July 2014; Scambos et al. 2014), based on satellite laser altimetry and satellite stereo-image elevation changes between 2001 and 2010. Based on available direct glaciological $B_{a}$ observations, Mernild et al. (2013; using $n=8$ glaciers) reported a mean glacier mass loss of $-830 \pm 280$ and $-210 \pm 230 \mathrm{~kg} \mathrm{~m}^{-2} \mathrm{yr}^{-1}$ for the Northern and the Southern Andes, respectively and $-130 \pm 100 \mathrm{~kg} \mathrm{~m}^{-2} \mathrm{yr}^{-1}$ for glaciers peripheral to the Antarctic Peninsula (2001-2010). These estimates take into account uncertainties related to under-sampling errors and geographical biases.

These three aforementioned studies are examples of $B_{a}$ estimates made for similar time periods but based on different approaches - together they represent a prediction that mass loss is much less in the Antarctic region and much greater in the north of the Andes Cordillera. However, much of this inference is based on interpolation models forced by limited ground-based observation.

On an individual glacier scale, Rignot et al. (2003), Davies and Glasser (2012), Willis et al. (2012a, 2012b), and Schaefer et al. (2013, 2015), for example, performed area and mass-balance analysis studies specifically for the Patagonia ice fields using radar observations, satellite-based observations, and simulations, respectively, whilst Kaser et al. (2003), Francou et al. (2004), Casassa et al. (2006), Pellicciotti et al. (2008), Vuille et al. (2008), Buttstadt et al. (2008), Rabatel et al. (2011, 2013), and MacDonell et al. (2013) performed mass-balance analysis for glaciers in Tierra del Fuego and the Andes Cordillera using the glaciological method, firn cores, and simulations. In several of these examples, $B_{a}$ time series were compared with different large-scale atmospheric and oceanic indices. However, these studies in general only include individual or few glaciers, observed over limited areas and periods. There thus remains a need for a more comprehensive spatiotemporal analysis of mass-balance trends for the regions discussed, along the Andes Cordillera to the sub-Antarctic islands, and their relationship with global climate indices.

In this study, we analyze 25 glacier $B_{a}$ time series available for South America (1993-2012) (including the northern (Region 1), central (Region 2), and southern Andes regions (Region 3)), and the sub-Antarctic islands located around the northern tip of the Antarctic Peninsula (Region 4) (Figure 1), in doing so improving the current spatial and temporal understanding of mass balance trends in these regions. 
We combine this larger than normal set of glacier estimates of $B_{a}$ with accumulation area ratio (AAR) methods which include specific routines for estimating undersampling errors and geographical biases (see Section 2.2). With these data and methods, we aimed to quantify: a) the glacier mass-balance conditions; b) the extent to which the glaciers sampled are out of balance with the present-day climate conditions; and c) the potential climate drivers of these patterns. In addition to the above effort, we focus on a glacier transect from the tropical latitudes in the northern part of South America to the tip of South America, emphasizing longitudinal gradients and differences in glacier conditions along the Andes Cordillera, and to the sub-Antarctic islands, across the Drake Passage (Figure 1). Our effort here is aimed at testing hypotheses as to whether sets of glaciers can be considered characteristically together or not, potentially challenging the current opinion that the South American glacier sample is comprised of three regions; a northern, central, southern region.

One way of understanding glacier mass-balance and imbalance conditions in a changing climate perspective is to compare $B_{a}$ time series with different large-scale atmospheric and oceanic indices, for example, the Multivariate El Niño Southern Oscillation (ENSO) (Wolter and Timlin 2011) and the Pacific Decadal Oscillation (PDO) (Zhang et al. 1997). These atmospheric circulation indices are considered good measures of airflow and moisture transport variability (e.g., Carrasco et al. 2005; Garreaud 2009; McClung 2013; López-Moreno et al. 2014) and this variation is considered to be important for glacier conditions (e.g., Francou et al. 2003, 2004; Favier et al. 2004; Vuille et al. 2008; Sagredo and Lowell 2012; Saltzmann et al. 2013; Veettil et al 2014; Malmros et al. 2015).

Glacier mass loss and the dramatic thinning in the northern Andes may be explained by the higher frequency of El Niño events and changes in their spatial and temporal occurrence together with a warming troposphere (Rabatel et al. 2013). Following this idea, in addition to the mass-balance and out of balance analysis, we evaluate the patterns of temporal and spatial glacier $B_{a}$ variations using an Empirical Orthogonal Function (EOF) analysis. We combine this with cross-correlations analyses relating $B_{a}$ patterns from South America and the sub-Antarctic islands to: 1 ) mesoscale atmospheric-ocean conditions, such as annual ENSO Index and PDO 4

values; and 2) to glacier elevations and aspects, in order to analyze statistical relations and better understanding their linkages. 


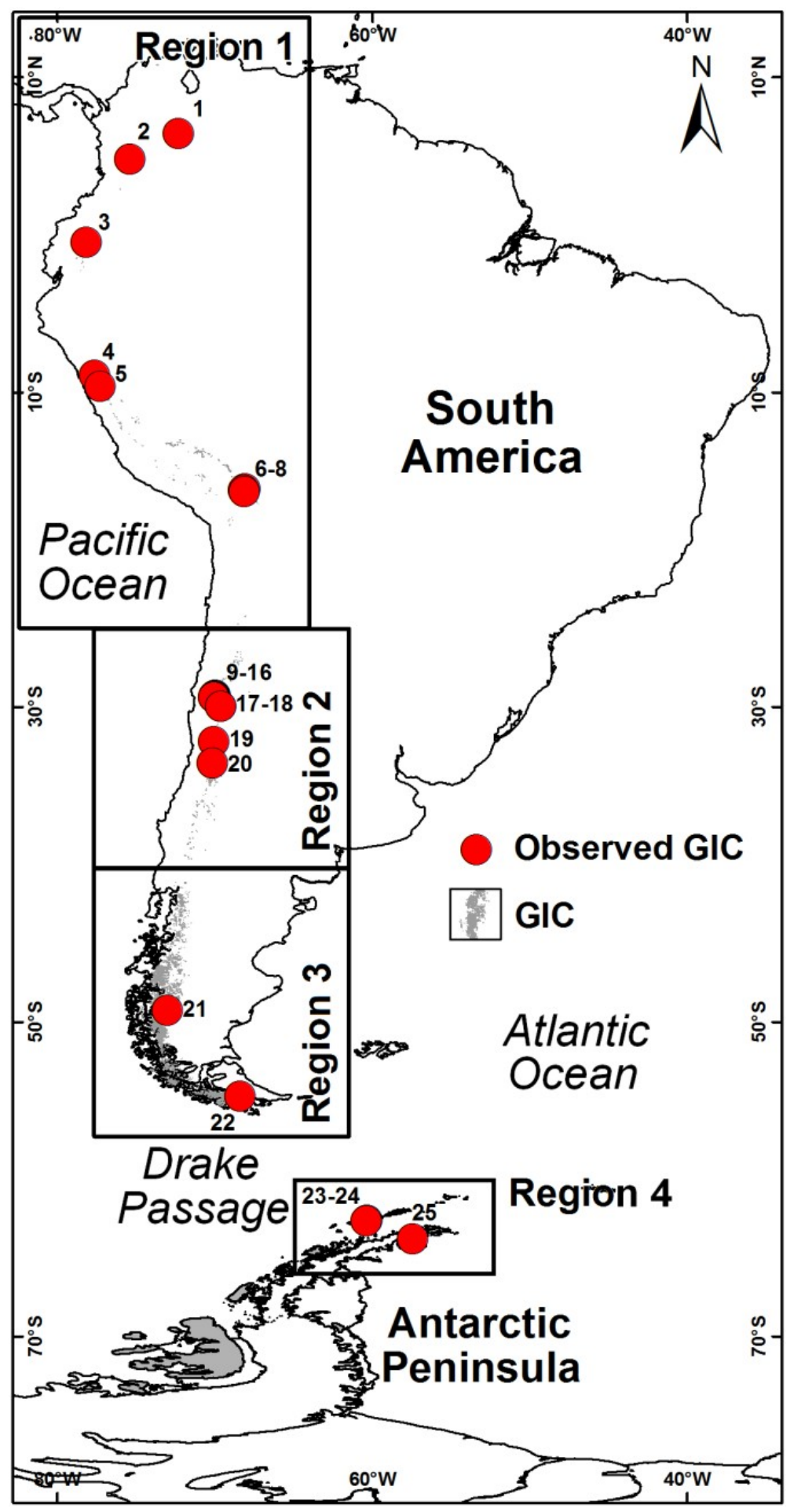

Figure 1: Locations of the 25 observed glaciers. The data are divided into four regions: Region 1 - Northern Andes (glacier Los Ritacubas (1), Conejeras (2), Antizana15Alpha (3), Artesonraju (4), Yanamarey (5), Charquini Sur (6), Zongo (7), Chacaltaya (8)); Region 2 - Central Andes (Los Amarillos (9), Amarillo (10), Toro 1 (11), Esperanza (12), Toro 2 (13), Guanaco (14), Otigas 2 (15), Otigas 1 (16), ConConta Norte (17), Brown Superior (18), Piloto Este (19), Echaurren Norte (20)); Region 3 - Southern Andes (De Los Tres (21), Martial Este (22)); and Region 4 the sub-Antarctic islands located around the northern tip of the Antarctic Peninsula (Johnsons (23), Hurd (24), and Bahia Del Diablo (25)). 


\section{Data and methods}

\subsection{Observed glaciers}

We compiled a dataset of observed annual $B_{a}\left(\mathrm{~kg} \mathrm{~m}^{-2} \mathrm{yr}^{-1}\right)$ for 25 glaciers spanning the period 1993 to 2012 for the continental mountain range transect along the Andes Cordillera $\left(6.5^{\circ} \mathrm{N}-45.8^{\circ} \mathrm{S}\right)$ to the sub-Antarctic islands $\left(62.7-63.8^{\circ} \mathrm{S}\right)$ (Figure 1). $B_{a}$ and AAR data originate from the World Glacier Monitoring Service (WGMS 2012, 2013, and earlier issues) database, with additional data from principal investigators, Dyurgerov and Meier (2005), Bahr et al. (2009), and Mernild et al. (2013). Both the $B_{a}$ and AAR samples used represent all data currently available for the regions of interest. Ideally, more $B_{a}$ observations might be needed in poorly sampled regions to overcome uncertainties. Unfortunately, no glacier AAR data were available for the Central Andes. The effect of debris cover on mass balance is not accounted for in this study and may potentially compromise the analyses of some of the observed glaciers.

The compiled glacier dataset was divided into four individual regions (the justification for doing so is presented in Section 3.2), and not, as proposed by Radić et al. (2013), into three regions: northern Andes, southern Andes, and the sub-Antarctic islands. Figure 1 shows the spatial distribution of the compiled glaciers, illustrating that eight glaciers are located in Region 1, 12 in Region 2, two in Region 3, and three in Region 4. As the mass-balance observations in Region 3, especially for glacier Martiel Este, represent lee-side mountain range conditions, in contrast to most other glaciers in the region (in Cordillera Darwin, Isla Santa Ines, Gran Campo Nevado, and parts of the Patagonian Ice Fields) which have upwind-side characteristics (especially in regards to their accumulation patterns), the observed $B_{a}$ are not fully representative of the southern Andes as a region and might therefore be biased towards lee-side accumulation conditions.

Figure 2 shows the observed time series of $B_{\mathrm{a}}$ for the period 1993-2012. We note that $25 \%$ of the $B_{a}$ observations are in the decade 1993-2002 and $75 \%$ in the decade 2003-2012. Therefore, the main temporal focus of this study will be on the latter period. Only glacier $B_{\mathrm{a}}$ time series longer than three years were included, with $\sim 90 \%$ of the glaciers having $B_{\mathrm{a}}$ time series longer than five years, $\sim 50 \%$ longer than ten years, and $\sim 20 \%$ longer than 15 years. The observed glaciers varied in size from 0.04 to $14.3 \mathrm{~km}^{2}$, with a median size of $0.3 \mathrm{~km}^{2}$. In comparison, the median glacier 
size from the Randolph Glacier Inventory v.3.2 (the Randolph Glacier Inventory is the first globally complete digital glacier database inventory; Arendt et al. (2012)) was 0.2 $\mathrm{km}^{2}$ for South America and the Antarctic/sub-Antarctic (Pfeffer et al. 2014). The observed glacier mid-elevation $\left(\mathrm{Z}_{\text {mid_elevation }}=\left(\mathrm{Z}_{\max }+\mathrm{Z}_{\min }\right) / 2\right.$, where $\mathrm{Z}_{\max }$ is the maximum glacier elevation and $Z_{\min }$ minimum elevation) varied from 4,800-5,450 m above sea-level (a.s.l) in Region 1, 3,770-5,240 m a.s.l. in Region 2, 1,070-1,525 m a.s.l. in Region 3, and 125-335 m a.s.l. in Region 4, indicating a decreasing midelevation with increasing southern latitudes (see also Troll (1973), Lliboutry (1998), and Pfeffer et al. (2014)).

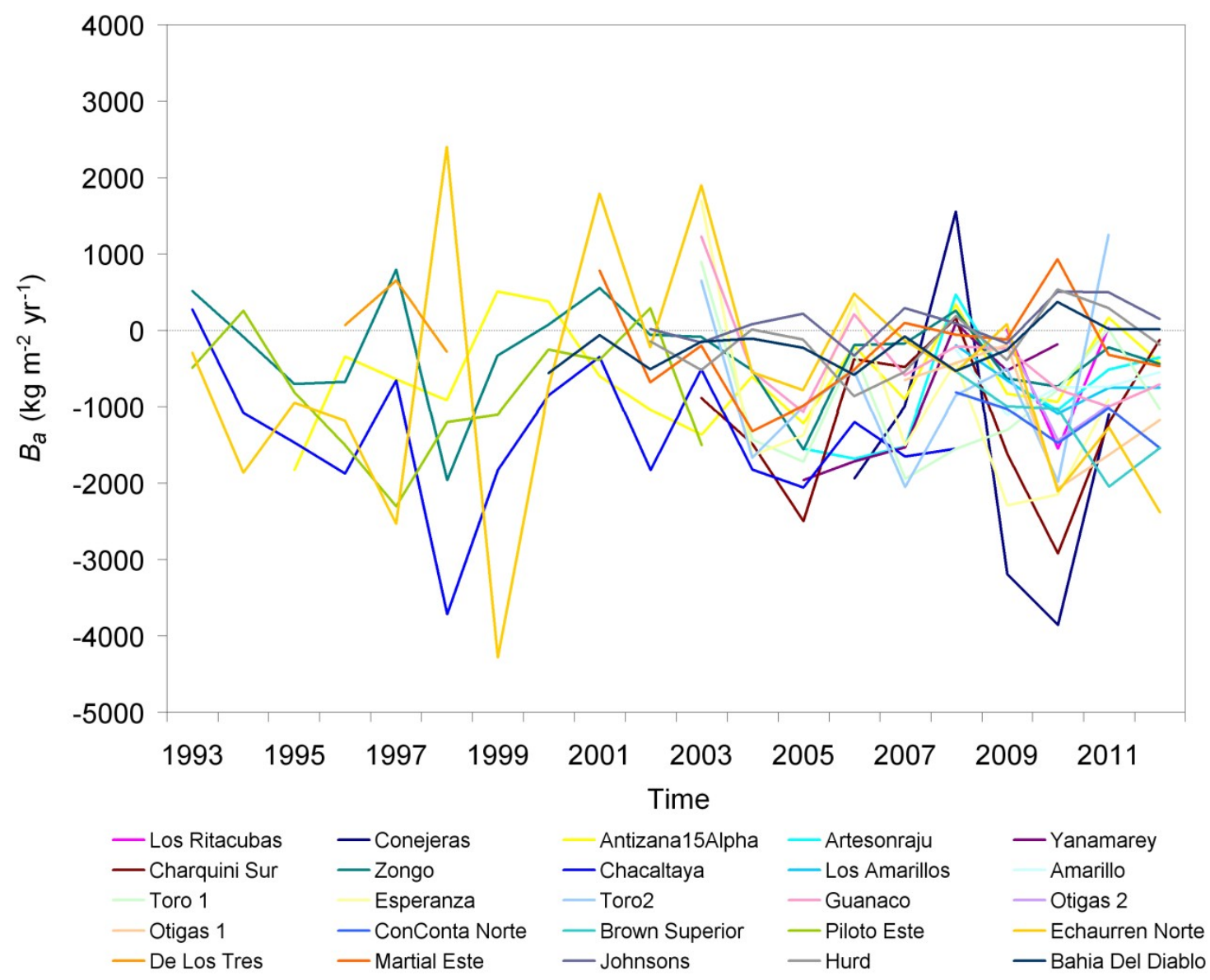

Figure 2: Time series of observed annual mass-balance $\left(B_{\mathrm{a}}\right)$ for the period 1993-2012 for glaciers located in South America and on the sub-Antarctic islands. 


\subsection{The EOF method}

In order to obtain a comprehensive spatiotemporal perspective on glacier $\mathrm{Ba}$, we performed an EOF analysis. The EOF analysis is widely used in atmospheric sciences and oceanography (e.g., Preisendorfer 1998; Sparnocchia et al. 2003). EOF analyses take the time by spatial location $\mathrm{Ba}$ data matrix and ordinates these data using singular value decomposition to return major axes of variation in Ba. When effective, the first few major axes of the EOF analysis performed here explain variation in $\mathrm{Ba}$ through time and in space (Figure 3). The eigenvectors associated with such an analysis are linked to spatial locations and thus reveal the influence of different geographic locations on the summarized Ba patterns, as well as suggesting further analyses of covariates associated with locations, such as altitude or aspect.

Additionally, each EOF is represented by a time series and this too can be related to other characteristics of the environment, including details of large-scale atmospheric and oceanic indices (e.g., ENSO and PDO).

For the EOF analysis, the data were centered around zero and scaled to unit variance (e.g., Mernild et al. 2014). The Data Interpolating Empirical Orthogonal Functions (DINEOF; Beckers and Rixon 2003) method was implemented in the statistical computing and graphic program ' $\mathrm{R}$ ' using the sinkr package (Taylor 2014, http://www.rdocumentation.org/packages/sinkr). The DINEOF method simultaneously interpolates missing data and returns the EOF axes and summary (Figure 3). Because the interpolation process involves randomization and permutation, we interpolated and estimated EOF for our data 50 times, estimating the number of EOFs and field for our set of $25 \mathrm{Ba}$ as the mean of these 50 replicates.

Our first assessment of the EOF analysis is spatial, addressed by examining the eigenvectors of the significant EOF's, which reflect the correlation for each site with the summary EOFs. Subsequently, we examined whether site features such as latitude, altitude, and aspect were linked to the EOFs.

Our second assessment involved using a cross-correlation analysis to quantify the strength of correlations between each EOF and two mesoscale atmospheric-ocean indices: the multivariate El Niño Southern Oscillation (ENSO) Index obtained from Wolter and Timlin (2011) and the Pacific Decadal Oscillation (PDO) obtained from Zhang et al. (1997). ENSO is comprised of different parameters being observed across the tropical Pacific Ocean, including sea-level pressure, sea-surface temperature (SST), surface air temperature, cloud fraction, and the zonal and meridional components of the surface wind. 
Normalized negative ENSO values represent La Niña events and positive values El Niño events. As an example, for the part of South America between $30^{\circ} \mathrm{S}-$ $35^{\circ} \mathrm{S}$, El Niño events have a tendency of being linked to above average annual precipitation, and vice versa during La Niña events (Rutllant and Fuenzalida 1991; Escobar et al. 1995; Montecinos and Aceituno 2002; Garreaud 2009; Wolter and Timlin 2011). The PDO reflects climate variability in the Pacific as well, but varies over a relatively longer time scale than the ENSO. The PDO may remain in the same phase for one to two decades, while ENSO cycles typically remain in the same phase for 6-18 months.

The PDO consists of warm (positive) and cold (negative) phases, defined by ocean SST anomalies in the northeast and tropical Pacific Ocean. These anomalies are implicated in upper level atmospheric winds causing droughts, and affect land-surface temperatures around the Pacific. When normalized SSTs are anomalously cool for the interior of the North Pacific and relatively warm near the equator and along the Pacific Coast (and when standardized sea-level pressure is below average over the North Pacific), the PDO has a positive phase, and vice versa for the negative phase. If ENSO and PDO are in the same phase, impacts from El Niño and La Niña are likely reinforced, and vice versa when they are out of phase (e.g., Yuan and Martinson 2000, 2001).

The use of cross-correlation analysis between the ENSO and PDO time series and the EOF summary time series can reveal contemporary or lagged correlations between the indices and the EOFs, thus helping to add insight into the timing and strength of forces driving the spatiotemporal $B_{a}$ patterns in South America and on subAntarctic islands. We estimated cross-correlations for both indices as the x- variable and the EOFs as y-variables, so that positive correlations are interpreted as the EOF of Ba lagging behind the indices (occurring with a delay or a lag-time of years).

Finally, the site specific correlations between EOF and glacier mid-elevation and dominant aspect were conducted to emphasize the topographical influence on $\mathrm{Ba}$, where the dominant aspect was calculated at 45 degree intervals (i.e., 360/0, 45, 90, etc). 
(a)
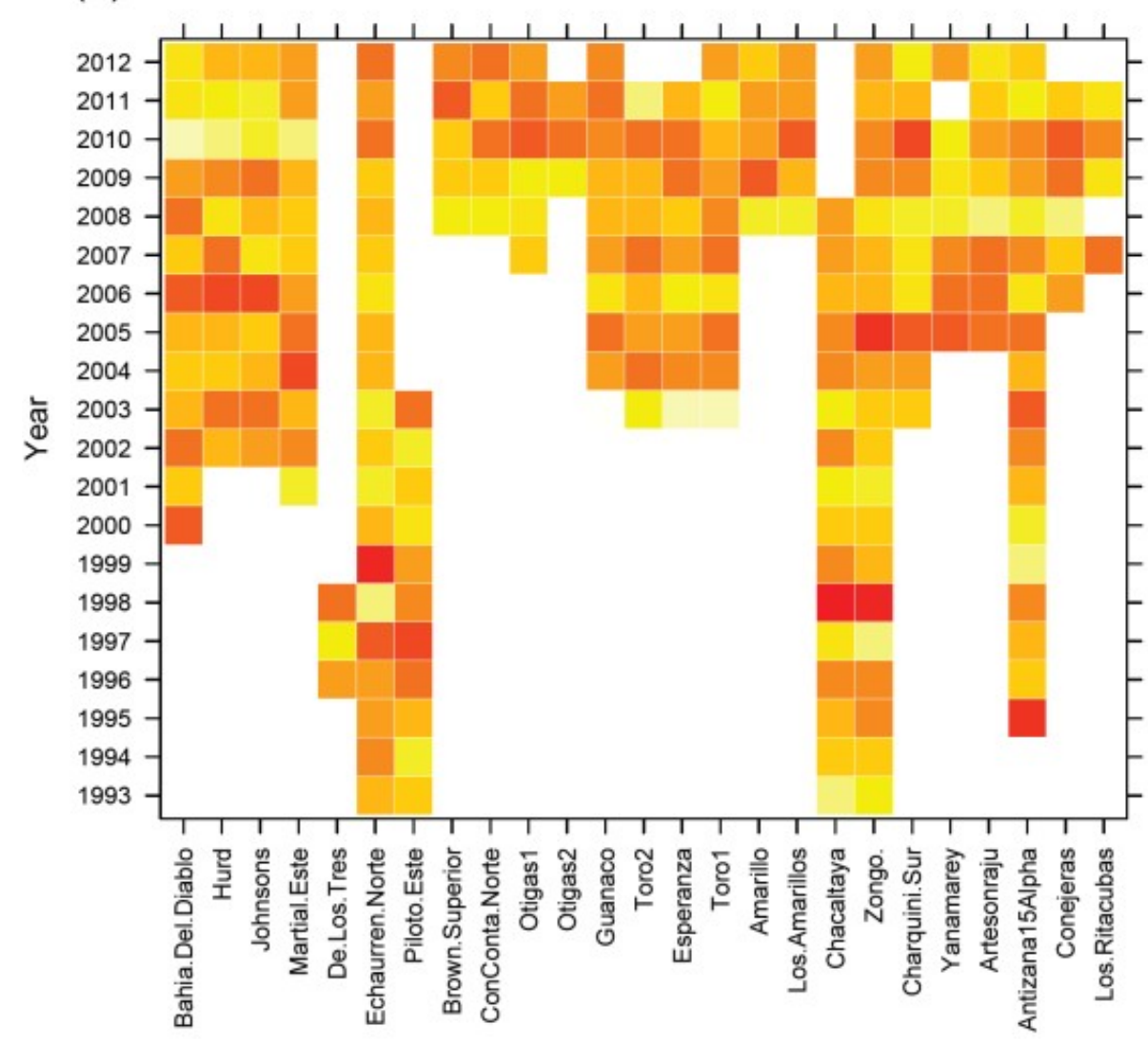

Location

\section{(b) Field - Interpolated}
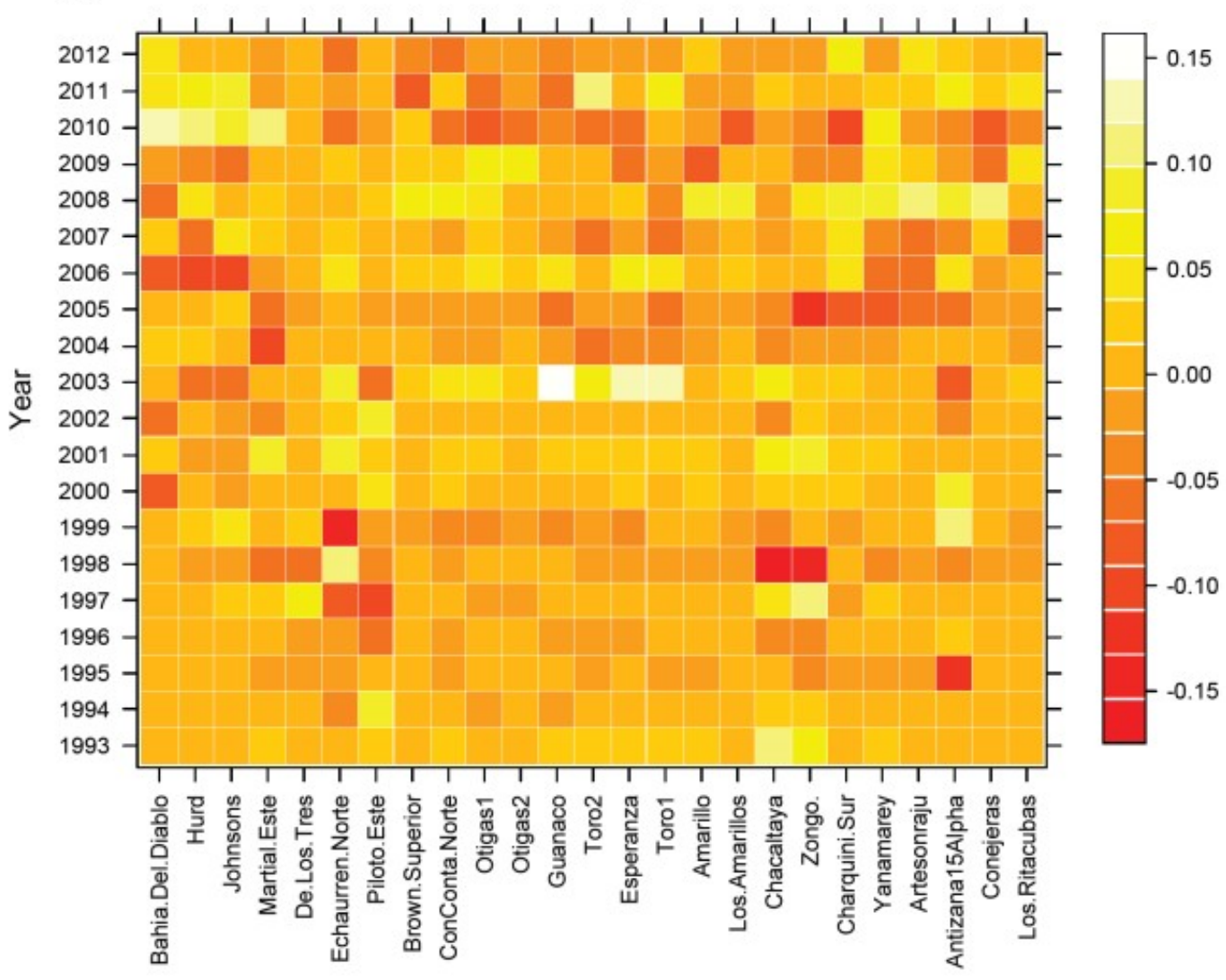

Location

Figure 3: Space-time field of the EOF analysis explaining variation in Ba (1993-2012), where the glacier locations from left to right go from south (the sub-Antarctic islands) to north (Colombia): (a) raw data field (the white squares equal no data, and the light yellow and red colors indicate a relatively strong variance); and (b) reconstructed data field. The reconstructed field is the mean of replicate reconstructions using the DINEOF method. The scale bar indicate the positive and negative variance. 


\subsection{The AAR method}

The AAR method, developed by Bahr et al. (2009), provides physical-based estimates of the committed area and volume losses for glaciers. For a glacier in balance with its local climate, AAR equals its equilibrium value $\mathrm{AAR}_{0}$. When $\mathrm{AAR}<$ $\mathrm{AAR}_{0}$, glaciers will thin and retreat from lower elevations until the AAR returns to equilibrium (e.g., Mernild et al. 2013). When AAR equals zero, glaciers have no accumulation zone and - if these conditions prevail - will eventually disappear within several decades or longer (Pelto 2010).

Expected changes in glacier area and volume can be derived from: $\alpha_{r}=\mathrm{AAR} /$ $\mathrm{AAR}_{0}$ (the ratio of the current AAR to its equilibrium $\mathrm{AAR}_{0}$ value). From $\alpha_{r}$, both the $p_{A}$ and $p_{V}$, the fractional changes in glacier area $(A)$ and volume $(V)$ required to reach equilibrium with a given climate, can be estimated. Bahr et al. (2009) showed that for a given glacier, $p_{A}=\alpha_{r}-1$ and $p_{V}=\alpha_{r}^{\gamma}-1$, where $\gamma$ is the exponent in the glacier volume-area scaling relationship, $\mu A^{\gamma}$ (Bahr et al. 1997). Data and theory $V$ suggest $\gamma=1.25$ for ice caps and $\gamma=1.375$ for glaciers, although these parameters may deviate significantly for individual GIC (Yde et al. 2014).

For the glaciers sampled here, $\mathrm{AAR}_{0}$ was computed by linear regression between $B_{a}$ and AAR (AAR $=m * B_{a}+\mathrm{AAR}_{0}$, where $m$ is the slope), and only retained where the regression was statistical significant (based on a linear regression $t$ test of the coefficients). AAR $=0$ and AAR $=100$ were excluded from this linear regression (but included in the broader analysis), since AAR and $B_{a}$ are not linearly related when net ablation and net accumulation occurs for the entire glacier (Mernild et al. 2013). We assume $\mathrm{AAR}_{0}$ to be constant in time (Dyurgerov et al. 2009). Also, we applied standard descriptive statistics such as decadal mean (1993-2002 and 2003-2012), standard deviation, and standard error values of Ba, AAR, $\alpha$, pA, and $\mathrm{pV}$.

The individual glacier area was correlated with $\alpha$ r based on the square of the linear correlation coefficient to emphasize that the glacier size was insignificant with $\alpha r(r 2=0.03)$. This calculation suggests that glacier size is not a large source of bias. A similar insignificant trend between area and $\alpha \mathrm{r}$ was found for the global observed glacier dataset $(n=144)$ used in Mernild et al. (2013; Figure 5), illustrating no global correlation between glacier area and $\alpha$. 


\subsection{Biases and errors}

Because several of our calculations are based on observations from less than $1 \%$ of the glaciers in South America and on the sub-Antarctic islands, issues of undersampling and geographically biases are important. We implemented several adjustments regarding these issues following Mernild et al. (2013; Appendix A and B), when estimating the regional errors for glacier $B_{a}, \mathrm{AAR}$, and $\alpha_{r}=\mathrm{AAR} / \mathrm{AAR}_{0}$. Error ranges computed from the dataset correspond to a $95 \%$ confidence interval, or 1.96 times the standard error, and all correlations labeled as 'significant' are at or above the $95 \%$ confidence level ( $p<0.05$; where $p$ is level of significance, indicating that there is $<5 \%$ probability that such a correlation was produced by chance). Such calculations are based on the null hypothesis.

\section{Results and discussion}

\subsection{Decadal mass-balance observations}

\subsubsection{South America and sub-Antarctic islands}

The decadal mean time series for the observed glacier $B_{a}$ between 1993 and 2012 are shown in Figure 4 for South America and the sub-Antarctic islands, and each of the four individual regions: northern Andes, central Andes, southern Andes, and the subAntarctic islands. For South America and the sub-Antarctic islands, the $B_{\mathrm{a}}$ time series show greater mean mass loss for the latest decadal period of $-700 \pm 210 \mathrm{~kg} \mathrm{~m}^{-2} \mathrm{yr}^{-1}(2003-$ 2012) (here and below, \pm equals the error range) than for the first decadal period $-620 \pm$ $390 \mathrm{~kg} \mathrm{~m}^{-2} \mathrm{yr}^{-1}$ (1993-2002) (Figure 4a and Table 1). However, the difference in $B_{\mathrm{a}}$ between the two decades is insignificant ( $97.5 \%$ quantile). The mean decadal change in $B_{a}$ for South America and the sub-Antarctic islands seems to follow the global mean decadal glacier Ba change shown in Cogley (2009, updated) and Kaser et al. (2006) (Figure 4a), where the global mean glacier Ba values from Cogley (2009, updated) were $-468 \pm 36 \mathrm{~kg}$ $\mathrm{m}-2$ yr-1 (1991-2000) and -787 $\pm 40 \mathrm{~kg} \mathrm{~m}-2$ yr-1 (2001-2010) and from Kaser et al. (2006) -420 \pm 145 kg m-2 yr-1 (1991-2004) and -510 \pm 101 kg m-2 yr-1 (2001-2004).

However, detailed Ba comparisons cannot be made with these two studies due to the differences in time periods. 

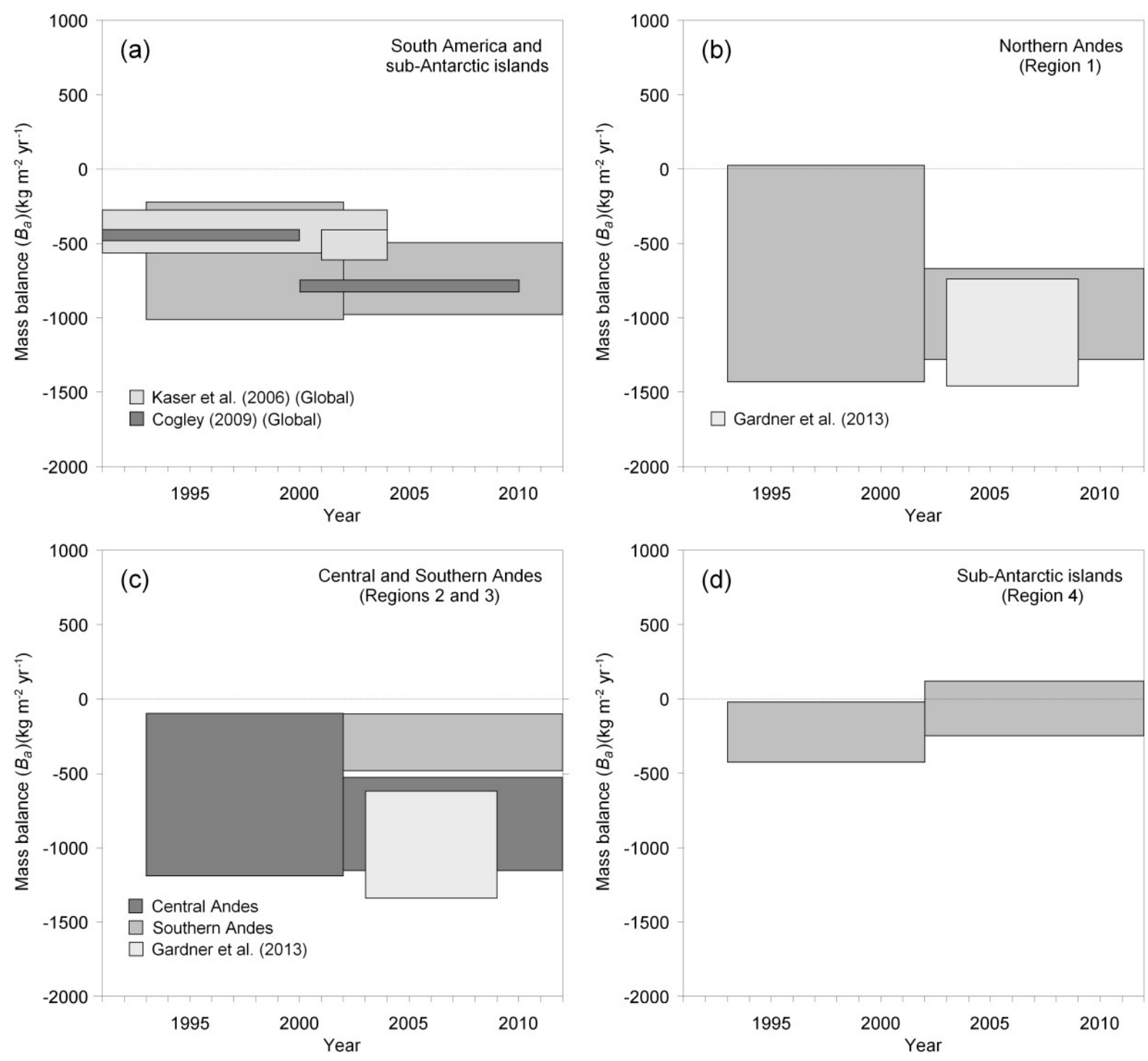

Figure 4: Decadal average Ba 1993-2012 with 95 \% confidence interval (the heights of the boxes cover the confidence interval over the interval) for: (a) South America and the subAntarctic islands, with global Ba data shown for comparison; (b) northern Andes (Region 1); (c) central Andes (Region 2) and southern Andes (Region 3); and (d) the sub-Antarctic islands (Region 4). Estimated global glacier Ba from Kaser et al.(2006) for 1991-2004 and 2001-2004 and Cogley (2009, updated) for 1991-2000 and 2001-2010, and regional glacier Ba from Gardner et al. (2013) for 2003-2009 are added.

Table 1: Mean values of $B_{a}$ for 2003-2012. Error ranges give $95 \%$ confidence interval.

\begin{tabular}{|c|c|c|c|c|c|}
\hline & $\begin{array}{c}\text { Northern } \\
\text { Andes } \\
\text { (Region 1) }\end{array}$ & $\begin{array}{c}\text { Central Andes } \\
\text { (Region 2) }\end{array}$ & $\begin{array}{c}\text { Southern } \\
\text { Andes } \\
\text { (Region 3) }\end{array}$ & $\begin{array}{c}\text { Sub-Antarctic } \\
\text { islands } \\
\text { (Region 4) }\end{array}$ & $\begin{array}{c}\text { South } \\
\text { America and } \\
\text { the sub- } \\
\text { Antarctic } \\
\text { islands }\end{array}$ \\
\hline $\begin{array}{c}B_{a} 1993-2002 \\
\left(\mathrm{~kg} \mathrm{~m}^{-2} \mathrm{yr}^{-1}\right)\end{array}$ & $-705 \pm 720$ & $-650 \pm 530$ & ---- & $-225 \pm 100$ & $-620 \pm 390$ \\
\hline $\begin{array}{c}B_{a} 2003-2012 \\
\left(\mathrm{~kg} \mathrm{~m}^{-2} \mathrm{yr}^{-1}\right)\end{array}$ & $-975 \pm 300$ & $-770 \pm 220$ & $-295 \pm 195$ & $-65 \pm 180$ & $-700 \pm 210$ \\
\hline
\end{tabular}




\subsubsection{Individual regions}

For the individual regions, the change in the decadal mean time series of the observed $B_{\mathrm{a}}$ was similar for the northern and central Andes regions (Figures $4 \mathrm{~b}$ and c), both indicating on average greater mass loss for the latest decade compared to the first decade (Table 1) (for the Southern Andes $B_{\text {a }}$ data were only available for the latest decade). An opposite change occurred for the sub-Antarctic islands, indicating on average greater mass loss for the first decade compared to the latest decade, where the decadal mean $B_{\mathrm{a}}$ for the latest decade was close to balance (zero) $-65 \pm 180 \mathrm{~kg} \mathrm{~m}^{-2}$ $\mathrm{yr}^{-1}$ (Figure 4d and Table 1). These sub-Antarctic island conditions seem to contradict satellite-derived mass balance estimations made for the northern Antarctic Peninsula $\left(<66^{\circ} \mathrm{S}\right)$, which has been identified as one of the most rapidly changing glaciated regions on Earth (e.g., Scambos et al. 2014) due to particular rapid atmospheric warming (mean air temperature increasing by $2.5^{\circ} \mathrm{C}$ from $1950-2000$ (Turner et al. 2005)).

Further, for three of the four individual regions (northern Andes, southern Andes, and the sub-Antarctic islands), the mean decadal $B_{\mathrm{a}}$ is not significantly different (97.5\% quantile) between the first and latest decade, even though the decadal $B_{\mathrm{a}}$ for northern Andes, southern Andes, and the sub-Antarctic islands changed by $-270 \mathrm{~kg} \mathrm{~m}^{-2},-120 \mathrm{~kg} \mathrm{~m}^{-2}$, and $120 \mathrm{~kg} \mathrm{~m}^{-2}$, respectively, resulting in a mean decadal $B_{\mathrm{a}}$ of $-975 \pm 300 \mathrm{~kg} \mathrm{~m}^{-2} \mathrm{yr}^{-1},-710 \pm 220 \mathrm{~kg} \mathrm{~m}^{-2} \mathrm{yr}^{-1}$, and $-65 \pm 180 \mathrm{~kg} \mathrm{~m}^{-2} \mathrm{yr}^{-1}$ for the latest decade (Figure 4 and Table 1). For the Northern Andes, for example, $B_{a}$ was estimated by Rabatel et al. (2013) to be $-800 \mathrm{~kg} \mathrm{~m}^{-2} \mathrm{yr}^{-1}$ and $-810 \mathrm{~kg} \mathrm{~m}^{-2} \mathrm{yr}^{-1}$ for the 1993-2002 and 2003-2010 periods, respectively. Longitudinally, the mean decadal $B_{\mathrm{a}}$ from the northern Andes to the sub-Antarctic islands the $B_{a}$ increased towards less negative values (2003-2012). For both the northern and central/southern Andes regions, we compared independent $B_{\mathrm{a}}$ values estimated by Gardner et al. (2013), for the period 2003-2009, based on satellite gravimetry, altimetry, and direct glaciological records, with the dataset compiled here: the result of this comparison indicated no significant difference (97.5\% quantile) in Ba.

3.2 EOF analysis of spatio-temporal mass-balance variation

Our DINEOF analyses suggests that the dataset can be summarized effectively by three major axes (modes) of EOF1, EOF2 and EOF3, representing $33 \%, 20 \%$, and $12 \%$, respectively, of the explained variance (Figure 5). North's Rule of Thumb (North et al. 1982) indicated that only EOF 1 was significant. However, we also present EOF2 because of its unique pattern linked to potential geographic separation of $\mathrm{Ba}$ trends, and the variance associated with it. 

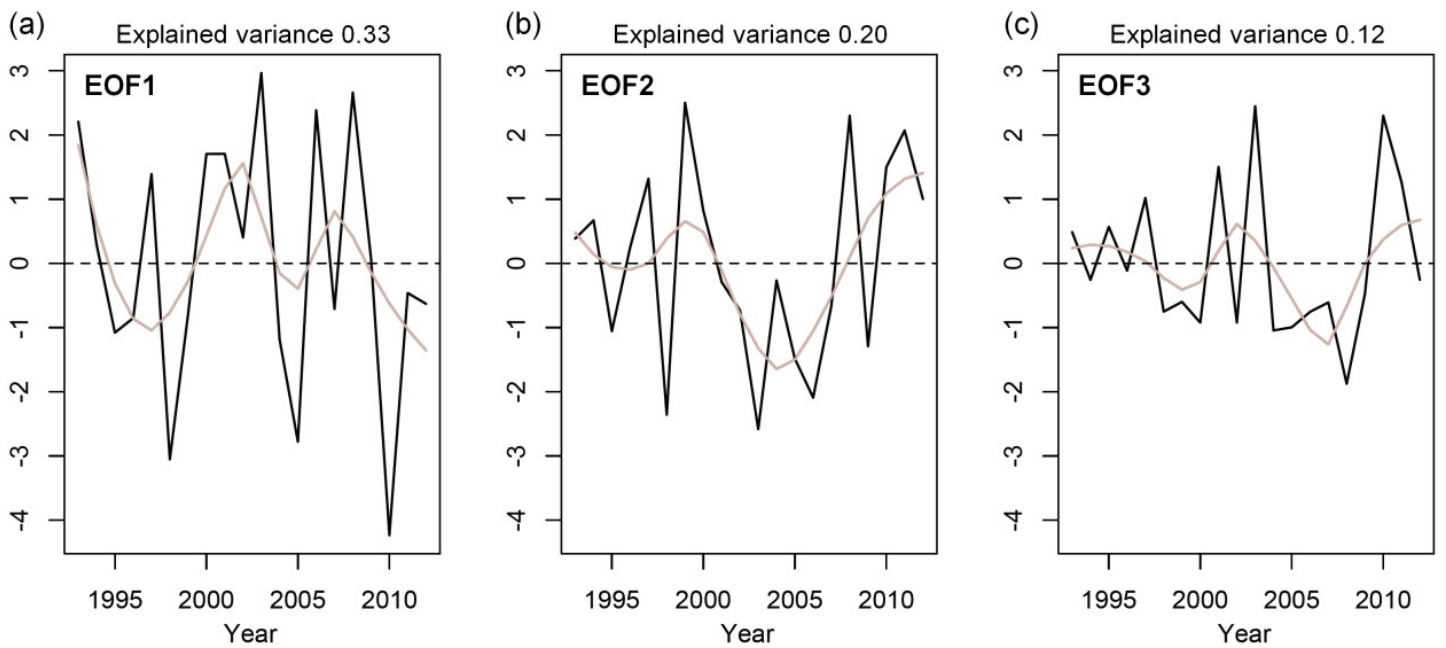

Figure 5: Ba time series (1993-2012) of the empirical orthogonal functions (black curve) and 5-years running mean smoothing line (grey curve): (a) EOF1; (b) EOF2; and (c) EOF3. The explained variance is shown for each EOF, where only EOF1 is significant.
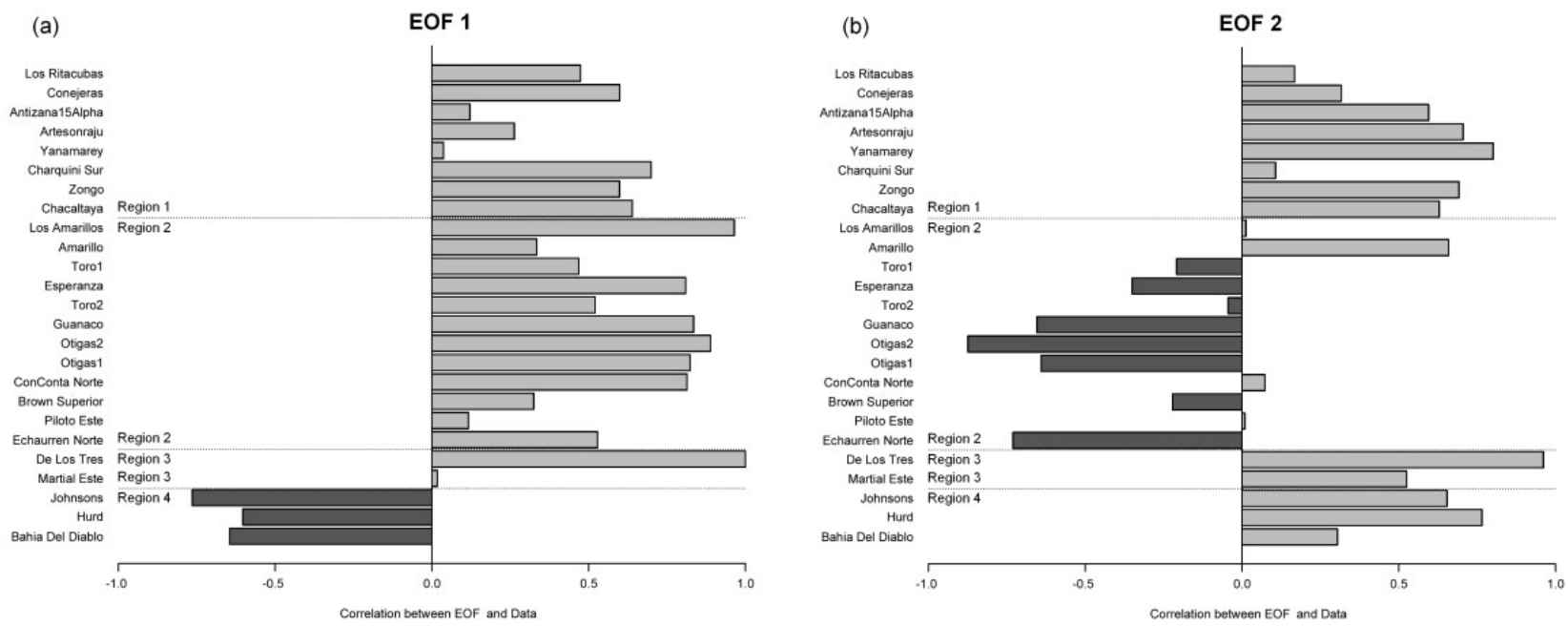

Figure 6: Eigenvector correlation values for each individual site for: (a) EOF1 and (b) EOF2. Locations are plotted in order of progressively higher latitude from top to bottom on each graph, ranging from the northern Andes (Region 1) to the subAntarctic islands (Region 4).

\subsubsection{EOF1 and geographic separation of $B_{a}$ trends}

Figures 5 and 6, show the temporal and spatial summary of the mass balance derived from the EOF analysis. In Figure 5a, the EOF1 5-years running mean smoothing line is positive between 1993-1995, 1999-2004, and 2006-2009, and negative between 1995-1999, 2004-2006, and 2009-2012. The temporal cycle of EOF 
patterns have associate spatial elements, derived from the eigenvectors (Figure 6). These show the correlations between the EOF values and patterns of mass balance for each individual glacier. Overall, the temporal trend in EOF 1, suggesting roughly decadal cycles of $\mathrm{Ba}$, is a pattern shared by nearly all glaciers, as indicated by the positively correlation for nearly all glaciers with EOF 1 values (Figure 6b).

Furthermore, we also found that low elevation glaciers (across latitudes) were negatively correlated with EOF1, suggesting, in this case, that elevation influences $B_{a}$ patterns (Figure 7). EOF 1 was not linked to glacier aspect.

(a)
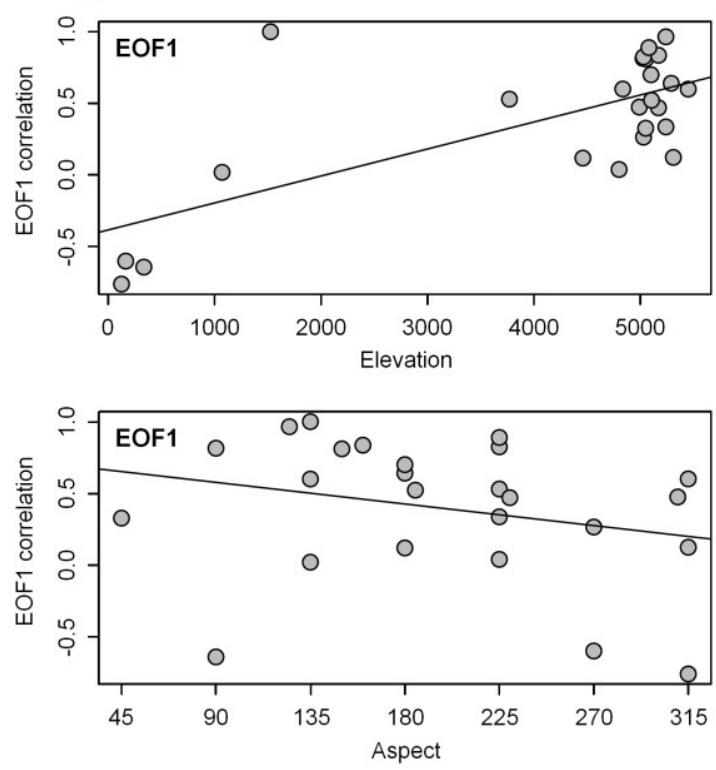

(b)
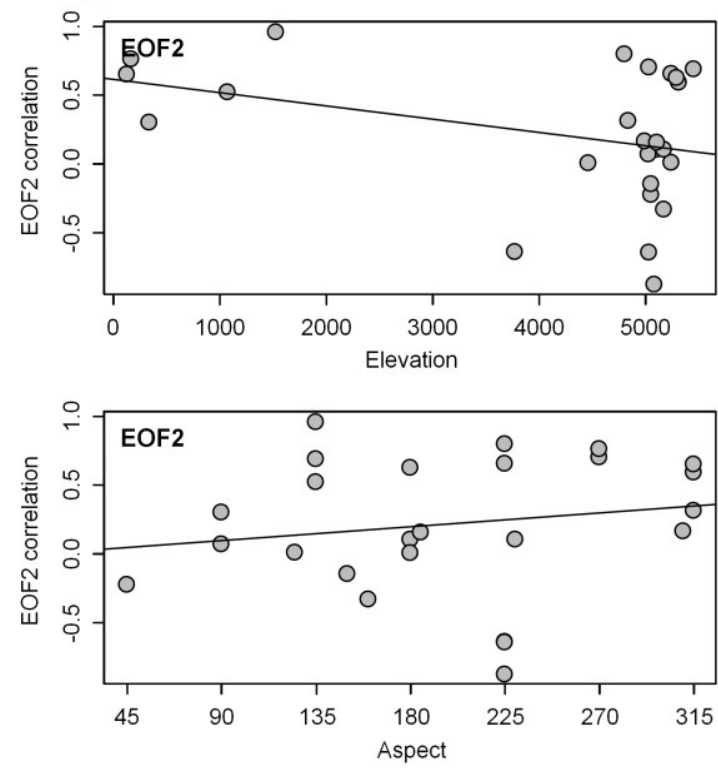

Figure 7: EOF correlations between mid-elevation and aspect (values ranging from 35 to 325 degree, where 180 degree = south): (a) EOF1; and (b) EOF2.

The three glaciers on the sub-Antarctic islands that are not strongly positively correlated with EOF 1 (Johnsons Glacier, Hurd Glacier, and Glacier Bahia Del Diablo) indicate a geographic separation - a distinct out of phase variation in $B_{\text {a }}$ time series on the sub-Antarctic islands in comparison to the rest of the dataset along the Andes Cordillera for the last two decades. This geographic separation is also illustrated in Figure $4 \mathrm{~d}$, where an opposite mean decadal $B_{\mathrm{a}}$ trend occurred, indicating greater mass loss for the first decade compare to the latest decade.

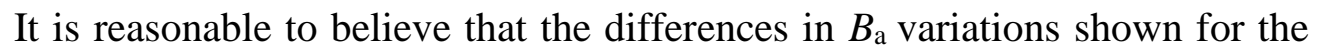
sub-Antarctic islands are brought about by existence of different climate forcing functions compared to the rest of the dataset. According to Li et al. (2014), the Antarctic Peninsula is influenced and dominated by climate forcing functions 
besides the radiative forcing and remote Pacific climate variability (e.g., Karoly 1989; Fogt et al. 2011). Other influences include forcings from the north and tropical Atlantic Ocean and from the Atlantic Multidecadal Oscillation (e.g., Schlesinger and Ramankutty 1994; Kaplan et al. 1998; Booth et al. 2012) (a leading mode of sea surface temperature variability). In contrast, the northern, central, and southern Andes regions are highly influenced by large-scale modes of natural variability in the Pacific oceans, e.g., variations in ENSO and PDO (Rosenbluth et al 1997; Schneider and Gies 2004; Garreaud 2009; Garreaud et al. 2009). Additionally, differences in topographical and local climate conditions between the sub-Antarctic islands and the Andes regions may also have an influence on the variability of $B_{a}$, where, for example, glaciers in northern and central Andes are located in cold and low humidity high mountain areas, and glaciers in the Southern Andes are located in all-year precipitation, mid-latitude, low- elevation and near-coastal climate conditions (Barry and Chorley 2009). In contrast, the glaciers on the sub-Antarctic islands are located in near-coastal maritime dominated climate conditions.

\subsubsection{EOF2 - three potential glacier regions for South America}

EOF2 (Figure 5b) has a temporal component that is roughly opposite of the temporal EOF1 pattern, though both patterns showed approximately the same frequency (Figure 5a). The EOF2 5-years running mean smoothing line is shown to be positive between 1993-1995, 1997-2001, and 2008 and onward, and negative between 19951997, and 2001-2008. The spatial correlations of EOF2 suggest that glaciers located in the central Andes (Region 2) (within a distance of $\sim 400 \mathrm{~km}$ ) vary differently in $B_{\mathrm{a}}$ from glaciers located in the northern Andes region (Region 1), in Patagonia (in the southern

Andes region, Region 3), and on the sub-Antarctic islands (Region 4) (Figure 6b). Further, we also found that high elevation glaciers were generally positively correlated with EOF2. As with EOF 1, there was no relationship with aspect (Figure 7).

The EOF2 dataset specifically suggests that $B_{a}$ at two sub-locations cycle in phase, while the other is out of phase with these two. The glaciers in the central Andes - Echaurren Norte, Brown Superior, Otigas 1 and 2, Guanaco, Toro 1 and 2, and Esperanza (glaciers having a mean $B_{a}$ time series of ten years) - are all negatively correlated with EOF2, and elsewhere in the dataset positively correlated with EOF2 (Figure 6b). Based on the EOF2 bar plots, this distribution suggests that area/regional variations in glacier $B_{a}$ time series for South America and the sub-Antarctic islands have occurred since 1993. 
Due to the existence of such variability, we suggest that glaciers are divided into three regions for South America, and not two as proposed by Radić et al. (2013). These three regions divide glaciers between the northern Andes, central Andes, and southern Andes, where the southern region should include the Patagonia area. The central Andes region should include the area between $25^{\circ} \mathrm{S}$ and $40^{\circ} \mathrm{S}$ south to the Lake District.

\subsection{Mesoscale climate indices and mass-balance variability}

The temporal meaning of $B_{\mathrm{a}}$ EOF summaries is revealed in the specific cross correlations with mesoscale atmospheric-ocean indices, such as PDO and ENSO. In Figure 8a, we show a positive correlation between EOF1 and PDO $\left(r^{2}=0.43\right)$ at a lag of 8 years, indicating that the variation in $B_{\mathrm{a}}$, which drives out of phase dynamic conditions between the sub-Antarctic island and South American glaciers, is linked to a lagged response to PDO. We also found a correlation between EOF1 and ENSO $\left(r^{2}=0.43\right)$ at a zero-lag, indicating real time covariation between the pattern in EOF1 and changes in ENSO. Again, this highlights that differences in spatial conditions between the subAntarctic islands and South American glaciers are likely linked to the ENSO.

Regarding the EOF2, we found no significant relationships with ENSO or PDO (Figure 8b), suggesting either that we do not have enough data to detect these relationships or that the spatiotemporal dynamics of glacier $B_{\mathrm{a}}$ captured in EOF2 is explained by other factors. 
(a)

EOF1
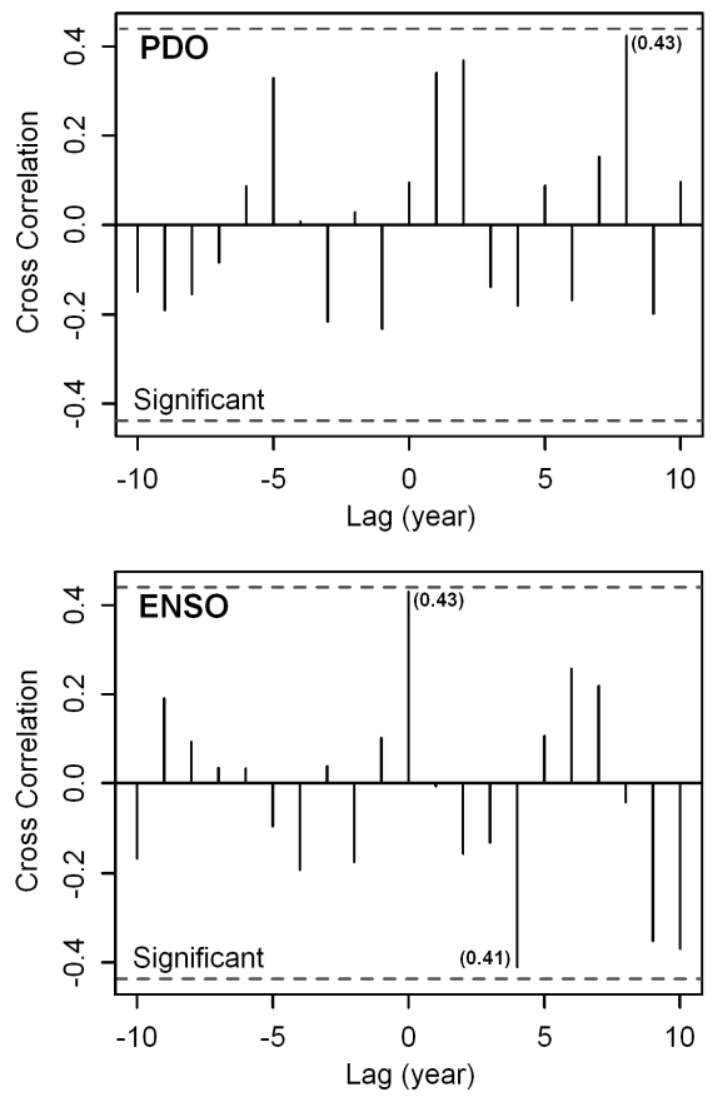

(b) EOF2
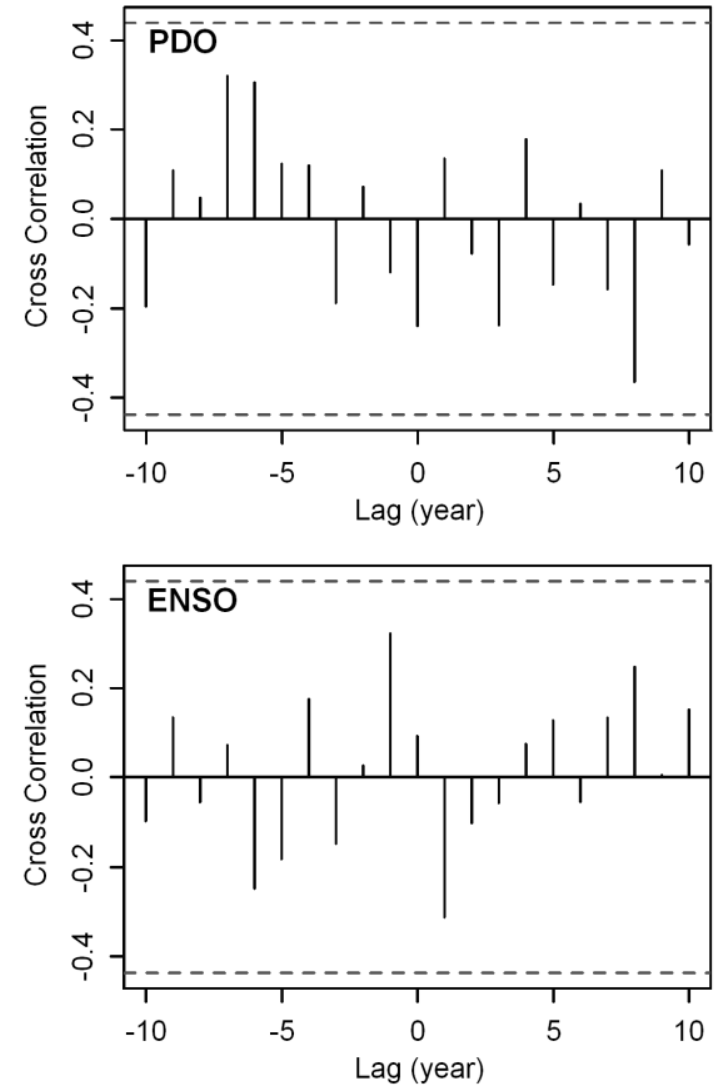

Figure 8: (a) EOF1 and (b) EOF2 cross correlation relationships between the PDO and ENSO. The horizontal dashed line indicates the line of significance (95\% confidence).

\subsection{Glacier imbalance conditions}

In general, glaciers worldwide are out of balance with the present-day climate (Bahr et al. 2009). To estimate the glacier imbalance conditions for South America and the sub-Antarctic islands, a period covering the latest decade (2003-2012) was used due to: 1) the good coverage of observations; and 2) because a ten-year period is long enough to analyze interannual mass-balance and climate variability but short in relation to glacier dynamic timescales (Mernild et al. 2013). For the dataset, we found that AAR $=0.42 \pm 0.13$ (2003-2012; Table 2), which is in the same range as the global average AAR of $0.44 \pm 0.02$ estimated by Dyurgerov et al. (2009) and shows that AAR $<$ AAR 0 , since $\mathrm{AAR}_{0}=0.51 \pm 0.11$ (and below the global average $\mathrm{AAR}_{0}$ of $0.579 \pm 0.9$ (Dyurgerov et al. 2009)). An AAR $<\mathrm{AAR}_{0}$ indicates that glaciers are out of balance with the present climate conditions. On a regional scale, AAR is shown to vary, with the lowest mean AAR value of $0.35 \pm 0.20$ shown for the northern Andes 
and the highest AAR value of $0.53 \pm 0.11$ shown for the sub-Antarctic islands (Table 2). The regional mean variability in AAR varies according to $B_{\mathrm{a}}$, where a low AAR corresponds to a low $B_{\mathrm{a}}$, and vice versa (Table 1). Only for the northern Andes is the AAR on average below the global average.

Table 2: Mean AAR for South America and the sub-Antarctic islands and on individual regional scale for 2003-2012. Error ranges give $95 \%$ confidence interval.

\begin{tabular}{|c|c|}
\hline & AAR, 2003-2012 \\
\hline South America and the sub-Antarctic islands & $0.42 \pm 0.13$ \\
\hline Northern Andes (Region 1) & $0.35 \pm 0.20$ \\
\hline Central Andes (Region 2) & ---- \\
\hline Southern Andes (Region 3) & $0.44 \pm 0.16$ \\
\hline Sub-Antarctic islands (Region 4) & $0.53 \pm 0.11$ \\
\hline
\end{tabular}

To estimate the expected changes in glacier area and volume, we found a mean $\alpha_{r}=\mathrm{AAR} / \mathrm{AAR}_{0}=0.77 \pm 0.20$ for South America and the sub-Antarctic islands, varying for individual regions from $0.67 \pm 0.15$ in the northern Andes, $0.78 \pm 0.16$ in the Southern Andes, to $0.96 \pm 0.20$ on the sub-Antarctic islands (2003-2012) (Table 3). The mean regional $\alpha_{r}$ values follow the mean regional $B_{\mathrm{a}}$ conditions, where a lowering in mass-balance results in a lowering of $\alpha_{r}$. On the annual scale, $\alpha_{r}$ and $B_{a}$ are closely correlated ( $r^{2}=0.53$, linear; Figure 9), indicating that a mass-balance bias of $100 \mathrm{~kg} \mathrm{~m}^{-2}$ $\mathrm{yr}^{-1}$ would be associated with biases of about 0.04 in $\alpha_{r}$. If the climate conditions of the 2003-2012 period (where 2001-2010 on global scale was the warmest decade on average since 1850 (IPCC 2013; Summary for Policymakers)) are to continue in the future, our calculations imply on average a committed area glacier loss for South America and for the sub-Antarctic islands around the northern tip of the Antarctic Peninsula of at least $23 \pm 20 \%$. 


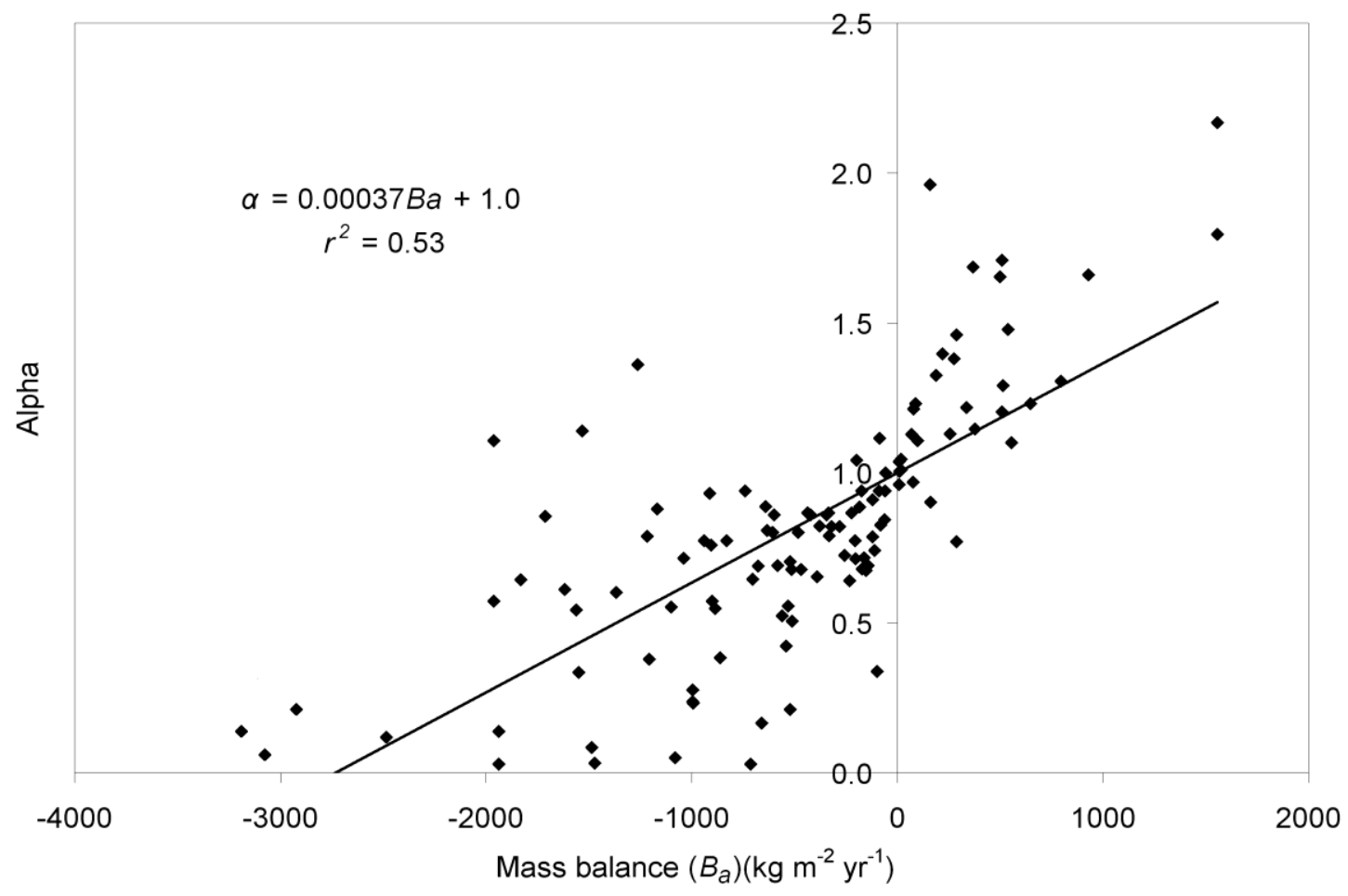

Figure 9: Linear relation between observed $B_{a}$ and alpha $\left(\alpha_{r}\right)=$ AAR/AAR 0 . Each diamond represents annual values. The regression line is forced to pass through the point $\left(B_{a}, \alpha_{r}\right)=(0,1)$, indicating that a mass-balance bias of $100 \mathrm{~kg} \mathrm{~m}^{-2} \mathrm{yr}^{-1}$ would be associated with biases of about 0.04 in $\alpha$. The trend is significant $(p<0.01$; as determined from the square correlation coefficient, $r^{2}$ ).

For the individual regions, the committed area glacier loss varies from $33 \pm 15$ $\%$ in the northern Andes, $22 \pm 16 \%$ in the southern Andes, and $4 \pm 20 \%$ on the subAntarctic islands, which equates to a total committed glacier volume loss of $27 \pm 23$ $\%$ and a regional glacier volume loss of $42 \pm 18 \%$, $28 \pm 20 \%$, and $5 \pm 26 \%$, respectively (Table 3). These committed glacier area and volume losses will force the glaciers to thin and retreat from lower elevations until AAR returns to equilibrium which might occur on a decadal-to-century time scale. The AAR approach used does not directly predict glacier thinning and retreating rates, but the typical response time for a glacier with a mean ice thickness of $100-500 \mathrm{~m}$ is in the range of 100 years according to theory (Johannesson et al. 1989). As the majority (97\%) of the glaciers in South America and on the sub-Antarctic islands have an estimated mean ice thickness of less than $100 \mathrm{~m}$ (estimated based on the RGI database and the glacier mean ice thickness-area scaling parameters from Bahr et al. (1997)), it is expected that the glaciers in South America and on the sub-Antarctic islands will thin and retreat over the 
next century, either until AAR returns to equilibrium or in some cases the glaciers disappear.

Table 3: Mean values of alpha $\left(\alpha_{r}\right)=\mathrm{AAR} / \mathrm{AAR}_{0}, p_{A}$, and $p_{V}$ for 2003-2012. Error ranges give $95 \%$ confidence interval.

\begin{tabular}{|c|c|c|c|c|c|}
\hline Region & $\begin{array}{c}\text { Northern } \\
\text { Andes } \\
\text { (Region 1) }\end{array}$ & $\begin{array}{c}\text { Central } \\
\text { Andes } \\
\text { (Region 2) }\end{array}$ & $\begin{array}{c}\text { Southern } \\
\text { Andes } \\
\text { (Region 3) }\end{array}$ & $\begin{array}{c}\text { Sub-Antarctic } \\
\text { islands } \\
\text { (Region 4) }\end{array}$ & $\begin{array}{c}\text { South } \\
\text { America and } \\
\text { the sub- } \\
\text { Antarctic } \\
\text { islands }\end{array}$ \\
\hline$\alpha_{r}$ & $0.67 \pm 0.15$ & ----- & $0.78 \pm 0.16$ & $0.96 \pm 0.20$ & $0.77 \pm 0.20$ \\
\hline$p_{A}(\%)$ & $33 \pm 15$ & ----- & $22 \pm 16$ & $4 \pm 20$ & $23 \pm 20$ \\
\hline S $p_{V}(\%)$ & $42 \pm 18$ & ----- & $28 \pm 20$ & $5 \pm 26$ & $27 \pm 23$ \\
\hline
\end{tabular}

\section{Summary and perspectives}

Our findings show that decadal $B_{\mathrm{a}}$ was negative on average from 1993 to 2012 for glaciers observed in South America, along the Andes Cordillera, and the subAntarctic islands, following the global mean decadal glacier $B_{\mathrm{a}}$ trend estimated by Cogley (2009, 2012). Longitudinally, the decadal $B_{\mathrm{a}}$ from the northern Andes to the sub-Antarctic islands increased on average towards less negative values from 1993 to 2012. On a regional scale, however, $B_{\mathrm{a}}$ trends were shown to be similar for the northern and central Andes regions, both indicating greater mass loss (insignificant) for the past decade (2003-2012) compared to the first decade (1993-2002). For the islands around the Antarctic Peninsula, an opposite glacier trend occurred, indicating on average greater mass loss for the first decade compared to the past decade. The negative $B_{\mathrm{a}}$ values shown for all regions for the past decade are the result of AAR conditions which are below the AAR value for glaciers in equilibrium, where glaciers on the subAntarctic islands on average are slightly out of balance, and glaciers in the Tropical Andes most out of balance.

Besides the mean decadal $B_{a}$ trends, the EOF analysis identified patterns of simultaneous temporal (annual) and spatial glacier $B_{a}$ variations. These patterns show that variations in $B_{\text {a }}$ time series on the sub-Antarctic islands are distinguished from the rest of the dataset in the Andes, and that the overall spatiotemporal cycle of $B_{a}$ captured in the EOF1 mode is linked to the PDO and ENSO with a $~ 8$ year and 0 year (instantaneous) lag time response, respectively. The instantaneous impact on the variations in $B_{a}$ from ENSO, and the cause of the delay from PDO seems clear, since 
ENSO cycles typically remain in the same phase for 6-18 months, whereas PDO can remain in the same phase for one-two decades.

The analyses of the present day glacier $B_{a}$ and imbalance conditions presented, including the comparisons to large-scale atmospheric and oceanic indices, are crucial for our regional understanding of glaciers and their influence on water balance conditions and hydrological flow regimes. A description of the present day glacier AAR condition is also crucial, since in a scenario of continuous atmospheric warming it is ultimately expected that glacier AARs will decrease towards zero, $B_{\mathrm{a}}$ will become more negative, and annual glacier runoff amounts will initially increase before subsequently declining as a reduction in glacier area offsets the effect of glacier melting (AMAP 2011).

\section{Acknowledgements}

This study was funded by Chilean FONDECYT (Project: \#1140172). We extent a very special thank to World Glacier Monitoring Service (WGMS) for providing us with data from the WGMS database. In addition, we thank the principal investigators of the WGMS network for sharing their observations with the community. The authors have no conflict of interest.

\section{References}

AMAP 2011. Snow, Water, Ice and Permafrost in the Arctic (SWIPA): Climate Change and the Cryosphere. Chapter 7: Mountain Glaciers and Ice Caps, 61 pp. Arctic Monitoring and Assessment Program (AMAP), Oslo, Norway, xii + 538 pp.

Bahr, D. B. 2011. Estimation of glacier volume and volume change by scaling methods, 278-280. In V. P. Singh, P. Singh, and U. K. Haritashya (Eds.), Encyclopedia of snow, ice, and glaciers (p. 1253). Dordrecht: Springer.

Bahr, D. B., Dyurgerov, M., and Meier, M. F. 2009. Sea-level rise from glaciers and ice caps: A lower bound. Geophysical Research Letters, 36, L03501, doi:10.1029/2008GL036309.

Barry, R, and Chorley, R. J. 2009. Atmosphere, Weather and Climate. $7^{\text {th }}$ edition. Routledge, London, pp 409. 
Beckers, J.-M. and Rixen, M. 2003. EOF Calculations and Data Filling from Incomplete Oceanographic Datasets. Journal of Atmospheric and Oceanic Technology, 20(12), 1839-1856. Bahr, D. B., Meier, M. F., and Peckham, S. D. 1997. The physical basis of glacier volume-area scaling. Journal of Geophysical Research, 102 (B9), 20355-20362.

Bliss, A., Hock, R., and Cogley, G. 2013. A new inventory of mountain glaciers and ice caps for the Antarctic periphery. Annals of Glaciology, 54(63), 191-199, doi:10.3189/2013AoG63A377.

Booth, B. B., Dunstone, N. J., Halloran, P. R., Andrews, T., and Bellouin, N. 2012. Aerosols implicated as a prime driver of twentieth-century North Atlantic climate variability. Nature, 484, 228-232.

Burga, C., Klötzli, F. and Grabherr, G. 2004. Gebirge der Erde - Land schaft, Klima, Pflanzenwelt. Ulmer, Stuttgart: 504 pp.

Buttstadt, M., Moller, M., Iturraspe, R., and Schneider, C. 2009. Mass balance evolution of martial Este Glacier, Tierra del Fuego (Argentina) for the period 19602099. Advances in Geosciences, 22, 117-124.

Carrasco, J. F., Casassa, G., Quintana, J. 2005. Changes of the $0^{\circ} \mathrm{C}$ isotherm and the equilibrium line altitude in the central Chile during the last quarter of the $20^{\text {th }}$ century. Hydrological Sciences - Journal des Sciences Hydrologiques, 50(6), 933-948, doi: 10.1623/hysj.2005.50.6.933.

Casassa, G., Rivera, A., Haeberlib, W., Jones, G., Kaser, G., Ribstein, P., and Schneider, C. 2007. Current status of Andean glaciers. Global and Planetary Change, 59, 1-9.

Casassa, G., Rivera, A., and Schwikowski, M. 2006. Glacier mass balance data for southern South America $\left(30^{\circ} \mathrm{S}-56^{\circ} \mathrm{S}\right)$. In KNIGHT, P.G., ed., Glacier Science and Environmental Change, Blackwell, Oxford, UK, pp. 239-241. 
Cogley, J. G. 2009. Geodetic and direct mass-balance measurements: comparison and joint analysis. Annals of Glaciology, 50(50), 96-100.

Cogley, J. G. 2012. The future of the world's glaciers. Pp. 197-222 in A. HendersonSellers and K. McGuffie, editors. The future of the world's climate. Elsevier, Amsterdam. The Netherlands.

Davis, B. J., Carrivick, J. L., Glasser, N. F., Hambrey, M. J., and Smellie, J. L. 2012. Variable glacier response to atmosphere warming, northern Antarctic Peninsula, 19882009. The Cryosphere, 6, 1031-1048. doi:10.5194/tc-6-1031-2012.

Davies, B. J. and Glasser, N. F. 2012. Accelerating shrinkage of Patagonian glaciers from the Little Ice Age ( 1870) to 2011. Journal of Glaciology, 58(212), 1063-1084.

Dyurgerov, M. B. 2010. Data of glaciological studies-reanalysis of glacier changes: from the IGY to the IPY, 1960-2008. Publication No. 108. Institute of Arctic and Alpine Research, University of Colorado, Boulder, Colorado, USA.

Dyurgerov, M. B. and Meier, M. F. 2005. Glaciers and the Changing Earth System: A 2004 Snapshot, Occas. Paper 58, 117 pp., Institute of Arctic and Alpine Research, Boulder, Colorado, 2005.

Dyurgerov, M., Meier, M. F., and Bahr, D. B. 2009. A new index of glacier area change; a tool for glacier monitoring, Journal of Glaciology, 55(192), 710-716, 2009.

Escobar, F., Casassa, G., and Pozo, V. 1995. Variaciones de un glaciar de Montaña en los Andes de Chile Central en las últimas dos décadas. Bull. Inst. Fr. Etudes Andines. (Lima), 24(3), 683-695.

Favier, V., Wagnon, P., and Ribstein, P. 2004. Glacier of the outer and inner tropics: a difference behavior but a common response to climatic forcing. Geophysical Research Letters, 31, L16403, doi:10.1029/2004GL020654.

Fogt, R. L., Bromwich, D. H., and Hines, K. M. 2011. Understanding the SAM influence on the Southern Pacific ENSO teleconnection. Climte Dynmaics, 36, 15551576. 
Francou, B., Vuille, M., Wagnon, P., Mendoza, J., Sicart, J. E. 2003. Tropical climate change recorded by a glacier in the central Andes during the last decade of the twentieth century: Chacaltaya, Bolivia, $16^{\circ}$ S. Journal of Geophysical Research, 108, 4154, doi:10.1029/2002JD002959.

Francou, B., Vuille, M., Favier, V., Caceres, B. 2004. New evidence for an ENSO impact on low-latitude glaciers: Antizana 15, Andes of Ecuador, $0^{\prime} 28^{\circ} \mathrm{S}$. Journal of Geophysical Research, 109, D18106, doi:10.1029/2003JD004484.

Gardner, A. S., Moholdt, G., Cogley, J. G., Wouters, B., Arendt, A. A., Wahr, J., Berthier, E., Hock, R., Pfeffer, W. T., Kaser, G., Ligtenberg, S. R. M., Bolch, T., Sharp, M. J., Hagen, J. O., van den Broeke, M. R., and Paul, F. A. 2012. Reconciled estimate of glacier contributions to sea level rise: 2003 to 2009. Science, 340(6134), 852-857.

Garreaud, R. D. 2009. The Andes climate and weather. Advances in Geosciences, 7, $1-9$.

Garreaud, R. D., Vuille, M., Compagnucci, R., Marengo, J. 2009. Present-day South American climate. Palaeogeography, Palaeoclimatology, Palaeoecology, 281(3-4), 180-195.

Georges, C. 2004. 20th-century glacier fluctuations in the tropical Cordillera Blanca, Perú. Arctic, Antarctic, and Alpine Research, 36(1), 100-107.

Hock, R., Woul, de M., Radić, V., and Dyurgerov, M. 2009. Mountain glaciers and ice caps around Antarctica make a large sea-level rise contribution. Geophysical Research Letters, 36, doi:10.1029/2008GL037020.

IPCC 2013. Observations: Cryosphere. Chapter 4. In: Climate Change 2013: The Physical Science Basis. Contribution of Working Group I to the Fifth Assessment Report of the Intergovernmental Panel on Climate Change [Stocker, T.F., D. Qin, G.K. Plattner, M. Tignor, S. K. Allen, J. Boschung, A. Nauels, Y. Xia, V. Bex and P. M. Midgley (eds.)]. Cambridge University Press, Cambridge, United Kingdom and New York, NY, USA. 
Jóhannesson, T., Raymond, C., and Waddington, E. 1989. Time-scale for adjustment of glaciers to changes in mass balance. Journal of Glaciology, 35, 355-369.

Kaplan, A., Cane, M. A., Kushnir, Y. and Clement, A. C. 1998. Analyses of global sea surface temperatures 1856-1991. Journal of Geophysical Research, 103, 1857518589.

Karoly, D. J. 1989. Southern hemisphere circulation features associated with El NinoSouthern Oscillation events. Journal of Climate, 2, 1239-1252.

Kaser, G., Juen, I., Georgen, C., Gomez, J., and Tamayo, W. 2003. The impact of glaciers on the runoff and the reconstruction of mass balance history from hydrological data in the tropical Cordillera Blance, Peru. Journal of Hydrology, 282(1-4), 130-144.

Kaser, G., Cogley, J. G., Dyurgerov, M. B., Meier, M. F., and Ohmura, A. 2006. Mass balance of glaciers and ice caps: consensus estimates for 1961-2004. Geophysical Research Letters, 33, L19501, doi:10.1029/2006GL027511.

Leclercq, P. W., Oerlemans, J., Basagic, H. J., Bushueva, I., Cook, A. J., Le Bris, R. 2014. A data set of worldwide glacier length fluctuations. The Cryosphere, 8, 659672, doi:10.5194/tc-8-659-2014.

Li, Xichen, Holland, D. M., Gerber, E. P., and Yoo, C. 2014. Impacts of the north and tropical Atlantic Ocean on the Antarctic Peninsula and sea ice. Nature, 505, 538-542, doi:10.1038/nature12945.

Lliboutry, L. 1998. Glaciers of South America I-6 - Glaciers of Chile and Argentina. In: U.S. Geological survey professional paper 1386-I, SATELLITE IMAGE ATLAS of Glaciers of the world. 1998, Edited by Richard S. Williams, Jr., and Jane g. Ferrigno, United States government printing office, Washington DC, USA.

López-Moreno, J.I., Fontaneda, S., Bazo, J., Revuelto, J., Azorin-Molina, C., ValeroGarcés, B., Morán-Tejeda, E., Vicente-Serrano, S.M., Zubieta, R. and Alejo- 
Cochachín, J. 2014. Recent glacier retreat and climate trends in Cordillera Huaytapallana, Peru. Global and Planetary Change, 112, 1-11.

MacDonell, S., Kinnard, C., Mölg, T., Nicholson, L., and Abermann, J. 2013. Meteorological drivers of ablation processes on a cold glacier in the semi-arid Andes of Chile. The Cryosphere, 7, 1513-1526, doi:10.5194/tc-7-1513-2013.

Malmros, J. K., Mernild, S. H., Wilson, R., Fensholt, R., and Yde, J. C. 2015. Glacier changes in the Rio Olivares catchment, central Chilean Andes, 1955-2013. In review Arctic, Antarctic, and Alpine Research.

Marzeion, B., Jarosch, A. H., and Hofer, M. 2012. Past and future sea-level change from the surface mass balance of glaciers. The Cryosphere, 6, 1295-1322.

Marzeion, B., Cogley, J. G., Richter, K., and Parkes, D. 2014. Attribution of global glacier mass loss to anthropogenic and natural causes. Science, doi: 10.1126/science 1254602.

Masiokas, M.H., Villalba, R., Luckman, B.H., Lascano, M.E., Delgado, S., and Stepanek, P. 2008. 20th-century glacier recession and regional hydroclimatic changes in northwestern Patagonia. Global and Planetary Change, 60, 85-100.

McClung, D. M. 2013. The Effects of El Niño and La Niña on snow and avalanche patterns in British Columbia, Canada, and central Chile. Journal of Glaciology, 59(216), 783-792.

Mernild, S. H., Hanna, E., McConnell, J. R., Sigl, M., Beckerman, A. P., Yde, J. C., Cappelen, J., and Steffen, K. 2014. Greenland precipitation trends in a long-term instrumental climate context (1890-2012): Evaluation of coastal and ice core records. International Journal of Climatology, doi:10.1002/joc.3986.

Mernild, S. H., Lipscomb, W. H., Bahr, D. B., Radić, V., and Zemp, M. 2013. Global glacier retreat: A revised assessment of committed mass losses and sampling uncertainties. The Cryosphere, 7, 1565-1577, doi:10.5194/tc-7-1565-2013. 
Montecinos, A. and Aceituno, P. 2002. Seasonality of the ENSO-Related Rainfall Variability in Central Chile and Associated Circulation Anomalies. Journal of Climate, 16, 281-296.

North, G. R., Bell, T. L., Cahalan, R. F., and Moeng, F. J. 1982. Sampling errors in the estimation of empirical orthogonal functions. Monthly Weather Review, 110, 699-706.

Pellicciotti, F., Helbing, J., Rivera, R., Favier, V., Corripio, J., Araos, J., Sicart, J.-E., Carenzo, M. 2008. A study of the energy balance and melt regime on Juncal Norte Glacier, semi-arid Andes of central Chile, using melt models of different complexity.Hydrological Processes, 22, 3980-3997.

Pelto, M. S. 2010. Forecasting temperate alpine glacier survival from accumulation zone observations. The Cryosphere, 4, 67-75, doi:10.5194/tc-4-67-2010.

Pfeffer, W. T., Arendt, A. A., Bliss, A., Bolch, T., Cogley, J. G., Gardner, A. S., Hagen, J.-O., Hock, R., Kaser, G., Kienholz, C., Miles, E. S., Moholdt, G., Molg, N., Paul, F., Radic, V., Rastner, P., Raup, B. H., Rich, J., Sharp, M. J., and The Randolph Consortium. 2014. The Randolph Glacier Inventory: a globally complete inventory of glaciers. Journal of Glaciology, 60(221), 537-552.

Preisendorfer, R. W. 1998. Principal Component Analysis in Meteorology and Oceanography, (Ed) Mobley, C. D., Elsevier, Amsterdam, pp. 452. tc-5-1029-2011.

Rabatel, A., Castebrunet, H., Favier, V., Nicholson, L., and Kinnard, C. 2011. Glacier changes in the Pascua-Lama region, Chilean Andes (29 $\mathrm{S})$ : recent mass balance and 50 yr surface area variations. The Cryosphere, 5, 1029-1041, doi:10.5194/ tc-5-1029-2011.

Radić, V. and Hock, R. 2010. Regional and global volumes of glaciers derived from statistical upscaling of glaciers inventory data. Journal of Geophysical Research, 15, F01010, doi:10.1029/2009JF001373. 
Radić, V., Bliss, A., Beedlow, A. C., Hock, R. Miles, E., and Cogley, J. G. 2013. Regional and global projection of twenty-first century glacier mass changes in response to climate scenarios from global climate models. Climte Dynmamics, doi $10.1007 / \mathrm{s} 00382-013-1719-7$.

Rignot, E., Rivera, A., and Casassa, G. 2003. Contribution of the Patagonia Icefields of South America to Sea Level Rise. Science, 302(5644), 434-437, doi:10.1126/science.1087393.

Rosenbluth, B., Fuenzalida, H. A., and Aceituno, P. 1997. Recent temperature variations in Southern South America. International Journal of Climatology, 17, 67- 85.

Sagredo, E.A. and Lowell, T.V. 2012. Climatology of Andean glaciers: A framework to understand glacier response to climate change. Global and Planetary Change, 86-87, 101-109.

Schneider, C. and Gies, D. 2004. Effects of El Niño-southern oscillation on southernmost South America precipitation at $53^{\circ} \mathrm{S}$ revealed from NCEP-NCAR reanalysis and weather station data. International Journal of Climatology, 24, 10571076.

Rutllant, J. and Fuenzalida, H. 1991. Synoptic aspects of the central Chile rainfall variability associated with the southern oscillation. International Journal of Climatology, 11(1), 63-76.

Saltzmann, N., Huggel, C., Rohrer, M., Silverio, W., Mark, B. G., Burns, P., and Portocarrero, C. 2013. Glacier changes and climate trends derived from multiple sources in the data scarce Cordillera Vilcanota region, Southern Peruvian Andes. The Cryosphere, 7, 103-118. doi:10.5194/tc-7-103-2013.

Scambos, T. A., Berthier, E., Haran, T., Chuman, C. A., Cook, A. J., Ligtenberg, S. R. M., and Bohlander, J. 2014. Detailed ice loss pattern in the northern Antarctic Peninsula: Widespread decline driven by ice front retreats. The Cryosphere Discussion, 8, 3237-3261. 
Schaefer, M., Hachguth, H., Falvey, M., and Casassa, G. 2013. Modeling past and future surface mass balance of the Northern Patagonia Icefield. Journal of Geophysical Research, Earth Surface, 118, doi:10.1002/jgrf.20038.

Schaefer, M., Hachguth, H., Falvey, M., Casassa, G., and Rignot E. 2015. Quantifying mass balance processes on the Southern Patagonia Icefield. The Cryosphere, 9, 25-35, doi:10.5194/tc-9-25-2015.

Schlesinger, M. E. and Ramankutty, N. 1994. An Oscillation in the global climate system of period 65-70 years. Nature, 367, 723-726.

Schaefer, M., Hachguth, H., Falvey, M., Casassa, G., and Rignot E. 2015. Quantifying mass balance processes on the Southern Patagonia Icefield. The Cryosphere, 9, 25-35, doi:10.5194/tc-9-25-2015.

Schlesinger, M. E. and Ramankutty, N. 1994. An Oscillation in the global climate system of period 65-70 years. Nature, 367, 723-726.

Sparnocchia, S., Pinardi, N., and Demirov, E. 2003. Multivariate Empirical Orthogonal Function analysis of the upper thermocline structure of the Mediteranean Sea from observations and model simulations. Annals Geophysical, 21, 167-187.

Troll, C. 1973. High mountain belts between the polar caps and the Equator: their definition and lower limit. Arctic and Alpine Research, 5(3), A19-A27.

Turner, J., Colwell, S. R., Marshall, G. J., Lachlan-Cope, T. A., Carleton, A. M., Jones, P. D., Lagun, V., Reid, P. A., and Iagovkin, S. 2005. Antarctic climate change during the last 50 years. International Journal of Climatology, 25, 279-294.

Veettil, B. K., Maier, E. L. B., Bremer, U. F., and de Souza. 2014. Combined influence of PDO and ENDO on Northern Andean glaciers: a case study on the Cotopaxi icecovered volcano, Ecuador. Climate Dynamics, doi: 10.1007/ s00382-014-2114-8. 
Vuille, M., Kaser, G., Juen, I. 2008. Gleacier mass balance variability in the Cordillera Blanca, Peru and its relationship with climate and the large-scale circulation. Global Planetary Change, 62, 14-28.

Willis, M.J., Melkonian, A.K., Pritchard, M.E., and Rivera, A., 2012a. Ice loss from the Southern Patagonian Ice Field, South America, between 2000 and 2012.

Geophysical Research Letters, 39, L17501-L17501.

Willis, M.J., Melkonian, A.K., Pritchard, M.E., and Ramage, J.M., 2012b. Ice loss rates at the Northern Patagonian Icefield derived using a decade of satellite remote sensing. Remote Sensing of Environment, 117, 184-198.

Wolter, K., and Timlin, M. S. 1993. Monitoring ENSO in COADS with a seasonal adjusted principal component index. Proceedings of the $17^{\text {th }}$ Climate Diagnostics Workshop, Norman, OK, NOAA/NMC/CAC, NSSL, Oklahoma Climate Survey, CIMMS and the School of Meterology, University of Oklahoma, Norman, OK, 52- 57.

Wolter, K., and Timlin, M. S. 2011. El Niño/Southern Oscillation behaviour since 1871 as diagnosed in an extended multivariate ENSO index (MEI.ext). International Journal of Climatology, 31(7), 1074-1087, http://www.esrl.noaa.gov/ psd/enso/mei/.

World Glacier Monitoring Service (WGMS) 2013. Glacier Mass Balance Bulletin 20102011 (Vol. 12), edited by: Zemp, M., Nussbaumer, S.U., Naegeli, K., Gärtner-Roer, I., Paul, F., Hoelzle, M. and Haeberli, W., ICSU (WDS) / IUGG (IACS) / UNEP / UNESCO / WMO, World Glacier Monitoring Service, Zurich, Switzerland, 106 pp., publication based on database version: doi: 10.5904/wgms- fog-2013-11.

World Glacier Monitoring Service (WGMS) 2012. Fluctuations of Glaciers 2005- 2010 (Vol. X), edited by: Zemp, M., Frey, H., Gärtner-Roer, I., Nussbaumer, S. U., Hoelzle, M., Paul, F., and Haeberli W., ICSU (WDS) / IUGG (IACS) / UNEP / UNESCO / WMO, World Glacier Monitoring Service, Zurich, Switzerland, 336 pp., Publication based on database version: doi:10.5904/wgms-fog-2012-11. 
Yde, J. C., Riger-Kusk, M., Løland, R., Ruud, H., Mernild, S. H., de Villiers, S., Knudsen, N. T., Malmros, J. K. 2014.Volume-area scaling at Mittivakkat Gletscher, southeast Greenland. Journal of Glaciology, 60(224), doi:10.3189/2014JoG14J047

Yuan, X. J., and Martinson, D. G. 2000. Antarctic sea ice extent variability and its global connectivity. Journal of Climate, 13(10), 1697-1717.

Yuan, X. J., and Martinson, D. G. 2001. The Antarctic Dipole and its predictability. Geophysical Research Letters, 28(18), 3609-3612.

Zhang, Y., Wallace, J. M., Battisti, D.S. 1997. ENSO-like inter-decadal variability: 1900-93. Journal of Climate, 10, 1004-1020, doi.org/10.1175/1520-0442(1997), www.ncdc.noaa.gov/teleconnections/pdo.php. 